\title{
Advanced Biofuels: Review of Effects on Environment and Socioeconomic Development
}

\author{
Rahil Akhtar Usmani ${ }^{1 *}$ \\ ${ }^{1}$ Department of Agriculture, Integral University, Lucknow, INDIA \\ *Corresponding Author: rahil7366@gmail.com \\ Citation: Usmani, R. A. (2020). Advanced Biofuels: Review of Effects on Environment and Socioeconomic Development. European Journal of \\ Sustainable Development Research, 4(4), em0129. https://doi.org/10.29333/ejosdr/8245 \\ ARTICLE INFO \\ Received: 17 Dec. 2019 \\ Accepted: 27 Apr. 2020

\begin{abstract}
In the current scenario when depleting crude oil sources pose a challenge against energy security the advanced biofuels seems as suitable alternate for transport sector. Because of lignocellulosic biomass based production advanced biofuels are considered as environment friendly and they have positive income and employment impacts on the socioeconomic conditions. The study has objectives to test the aforementioned claims on the basis of a review of available literature. It is found that the GHG emission from conventional biofuels is not as much lower as claimed. But the advanced biofuels found to be more environment friendly than their counterparts. The data on socioeconomic impacts of advanced biofuel is scarce and only available for the USA which is reported in this study. It is found that the agriculture sector is significantly benefited sector by the industrial scale production of the advanced biofuels. For the assessment of large scale impacts it is assumed that the dynamics of spreading of socioeconomic impacts of advanced biofuels industry is same as the conventional biofuel industry. On the basis of aforementioned observations, this study also supports the notion of positive environmental and socioeconomic
\end{abstract} \\ impacts of the advanced biofuels but on the conditions of sustainable and decarbonized supply chain.
}

Keywords: advanced biofuels, environment, greenhouse gas, socioeconomic impacts, farmer's income, rural development

\section{INTRODUCTION}

Biomass is the primary renewable energy source and $\sim 40 \%$ of the global population rely on the biomass for their energy needs (Sakthivadivel and Iniyan, 2018). The group of liquid and gaseous fuels produced by biomass is known as biofuels, and biofuels explicitly produced from the lignocellulosic biomass is known as advanced biofuels (Hamelinck and Faaij, 2006; Tanaka, 2010). Liquid and gaseous biofuels have application for the transport sector. The growth of transport sector led to the over-exploitation of crude oil sources and put the supply security at risk. Further, the greenhouse gas (GHG) emission from transport sector is responsible for the $23 \%$ of the world's energy-related emissions (Ribeiro et al., 2007). Biofuels are considered as renewable and sustainable transport fuels because they have properties like lesser emissions of greenhouse gasses and particulate matter (Demirbas, 2008). The reason for lesser GHG emissions is the presence of significant oxygen content (10\% - 45\%) in biofuels, while fossil fuels do not have oxygen in their molecular structure. Due to higher oxygen content, biofuels have better antiknock value and combust efficiently with reduced GHG emissions (A Demirbas, 2009).

Presently, food based biofuels or conventional biofuels have dominating share in market. The credit goes to their relatively simple and mature production technology and well-developed supply chain. The feedstock for these biofuels includes starch and sugar containing crops for ethanol production and oilseeds for biodiesel production (Ayhan Demirbas, 2009). The continuous use of food biomass for biofuel production instigates the food versus fuel debate. Additionally, conventional biofuels are also not costcompetitive with the existing petroleum based fuels without subsidies except Brazilian ethanol from sugarcane (Larson and Larson, 2008). Further, their environmental sustainability is in question after considering the emission from the entire supply chain (Araújo et al., 2017).

Because of production from novel technologies and lignocellulosic biomass, advanced biofuels are considered as more suitable than the conventional biofuels. Biomass from agricultural and woody residues are widely used as feedstock for energy production (Sakthivadivel et al., 2019). Lignocellulosic biomass is not used as food and are available in large quantity. It is estimated that the worldwide quantity of biomass by terrestrial plants is around 170-200 × $109 \mathrm{Gt}$ (Giga tonne) (Pauly and Keegstra, 2008).

The objective of this study is to evaluate the environmental sustainability and socioeconomic impacts of advanced biofuels via a review of existing literature. It is well known that in today's world the success of any industry is evaluated in terms of its 
positive impacts on the environment and society which is as equally important as the economic and monetary gains. For the evaluation of environmental impacts of advanced biofuels, data on GHGs emission by the combustion of advanced biofuels for releasing of one mega joule $(\mathrm{MJ})$ of energy is collected and evaluated from the available literature. The data available on advanced biofuel's socioeconomic impacts is limited. Therefore, for the evaluation of their economic and social benefits, it was assumed that the dynamics of spreading of these effects over society are the same as of conventional biofuels. Due to this, mostly the data and examples are taken from the conventional biofuel industry. The study is structured as follows; section two highlights the environmental impacts of the advanced biofuels and; section three deals with the socioeconomic impacts.

\section{ENVIRONMENTAL IMPACTS}

\section{GHG Emissions and Transport Sector}

GHGs include Carbon dioxide $\left(\mathrm{CO}_{2}\right)$, Carbon monoxide $(\mathrm{CO})$, Methane $\left(\mathrm{CH}_{4}\right)$, Nitrous Oxide $\left(\mathrm{N}_{2} \mathrm{O}\right)$, Ozone $\left(\mathrm{O}_{3}\right)$ and Chlorofluorocarbons (CFCs). Carbon dioxide is the most abundant GHG and represents $76 \%$ of the total GHGs (combined emission from transport, agriculture and industry). GHGs traps solar heat and help in maintaining the life-sustaining atmospheric temperature (Change, 2015). Due to the heat-trapping property, the excess of these gases causes additional rise in temperature than is required in the ecosystem. This unnecessary warming of atmosphere is termed as the 'global warming'.

After the industrial revolution, the atmospheric concentration of carbon dioxide escalated by $36 \%$. The use of fossil fuels in transport and industrial sector is the major cause of rising atmospheric concentration of $^{\mathrm{CO}_{2}}$ (Change, 2015). The massive consumption of fossil fuels was responsible for 6.3 Giga tonne (Gt) of carbon dioxide emission in 2004 (Ilyama, Kariuki, Kristjanson, Kaitibie, and Maitima, 2008). The transport sector is the end user of liquid petroleum fuels and consumes $\sim 95 \%$ of the supply. Since 1990 , the emission from road transport had been increased by $68 \%$ and is responsible for $75 \%$ of the transport sector emissions in 2013 (IEA, 2015). Globally, transport fuel consumption is growing at the rate of $2 \%$ per year and this rate of growth is expected to maintain in the coming years (Eisentraut, Brown, and Fulton, 2011).

\section{Advanced Biofuels for Transport Sector}

Advanced biofuels are produced from the lignocellulosic biomass which is non-edible and available in huge quantity. Approximately, $70 \%$ of the total terrestrial biomass is considered as lignocellulose (Pauly and Keegstra, 2008). Also, purposively cultivated energy crops which include Miscanthus, Switchgrass, perennial grasses, etc. could be an additional source of the lignocellulosic biomass. These energy crops can grow on marginal land without much requirements of input and care. Thus, in their complete life cycle, they could prove to be a better option for GHG mitigation (Larson and Larson, 2008; Petroleum, 2013).

The blending of transport fuels with biofuels has significant positive impact on GHG emissions. For instance, the mixing of ethanol in gasoline resulted in more efficient combustion of gasoline with a lesser emission of particulate matter and GHGs (Greene et al., 2004). The blending of ethanol also replaced the tetraethyl led which is an anti-knocking agent and a pollutant. Blending results in the replacement of petroleum fuels in the same proportion. For example, the $10 \%$ blend of ethanol reduces $10 \%$ use of gasoline, which resulted in $10 \%$ lesser carbon emitted in the atmosphere (Kheshgi, Prince, and Marland, 2000) (Ladanai and Vinterbäck, 2010).

\section{GHG Emissions and Advanced Biofuels}

The lower GHGs emissions is a key facet of environmental sustainability of the advanced biofuels. There is a growing recognition that advanced biofuel technologies are more carbon neutral and promising for GHG mitigation (Eisentraut, Brown, and Fulton, 2011). Evidence of the GHG emission from the Life Cycle Analysis (LCA) of cellulosic ethanol is presented here (Table 1). It is the most studied advanced biofuel and there is a huge optimism regarding their GHG reduction abilities. The optimism is based upon the fact that cellulosic ethanol requires a lesser quantity of fossil fuel inputs in their production as compared to other conventional biofuels (Eisentraut, 2010b; Farrell, 2006; Lynd, 1996).

Table 1. GHG emissions from ethanol produced by different type of feedstock

\begin{tabular}{cccc}
\hline Study & GHGs (gCO2 e/MJ) & Feedstock & Source \\
\hline Hamelinck & $37-64$ & Corn & (Hamelinck, De Loveinfosse, and Koper, 2012) \\
\hline Eisentraut & $77-105$ & Corn of which 30 g CO2-eq/MJ is from iLUC & (Eisentraut, 2010a) \\
\hline Eisentraut & 95 & Gasoline & (Eisentraut, 2010a) \\
\hline Hamelinck & 11 & Lignocellulose & (Hamelinck, De Loveinfosse, and Koper, 2012) \\
\hline Purohit & $21.6-23.1$ & Lignocellulose (straws) & (Purohit and Fischer, 2014) \\
\hline Eisentraut & 22 & Lignocellulose (wood and forestry residues) & (Eisentraut, 2010a)
\end{tabular}

Table 1 shows the GHG emissions for obtaining a one MJ of energy by the combustion of ethanol produced from different sources of lignocellulosic biomass and ethanol produced from corn grains. The emission from gasoline has used as a benchmark for identification of the real GHG savings which is $95 \mathrm{gCO}_{2}-\mathrm{e}$ (gram carbon dioxide equivalent per mega joule) for obtaining one $\mathrm{MJ}$ of energy. Corn ethanol emits in between $37-105 \mathrm{gCO}_{2}-\mathrm{e} / \mathrm{MJ}$, when emission from the indirect land use change (iLUC) is added in the LCA. Without addition of iLUC in LCA, the total emission from corn ethanol is in between $37-64 \mathrm{gCO}_{2}-\mathrm{e} / \mathrm{MJ}$.

The GHG emission from cellulosic ethanol is in between the range of $11-23 \mathrm{gCO}_{2}-\mathrm{e} / \mathrm{MJ}$. A study reported $12.3-12.4 \mathrm{gCO}$-e/MJ emission for ethanol obtained from lignocellulosic biomass (Khan and Usmani, 2016). The conversion of straws into ethanol emission emits 21.6 - 23.1 gCO2-e/MJ (Table 1). The range of GHG emission by ethanol from different lignocellulosic biomass is significantly lower than ethanol produced from corn and the gasoline. 
Figure 1 represents the range of $\mathrm{CO}_{2}$ emission by biofuels produced from different types of biomass and gasoline. It is clear from Figure 1 that the $\mathrm{CO}_{2}$ emission from corn ethanol is approximately equal to that from gasoline if the emission from land use change has been taken into consideration. It means, the indirect clearing of carbon-intensive areas for production of corn crop have negative effects on GHG emission savings achieved by corn ethanol.

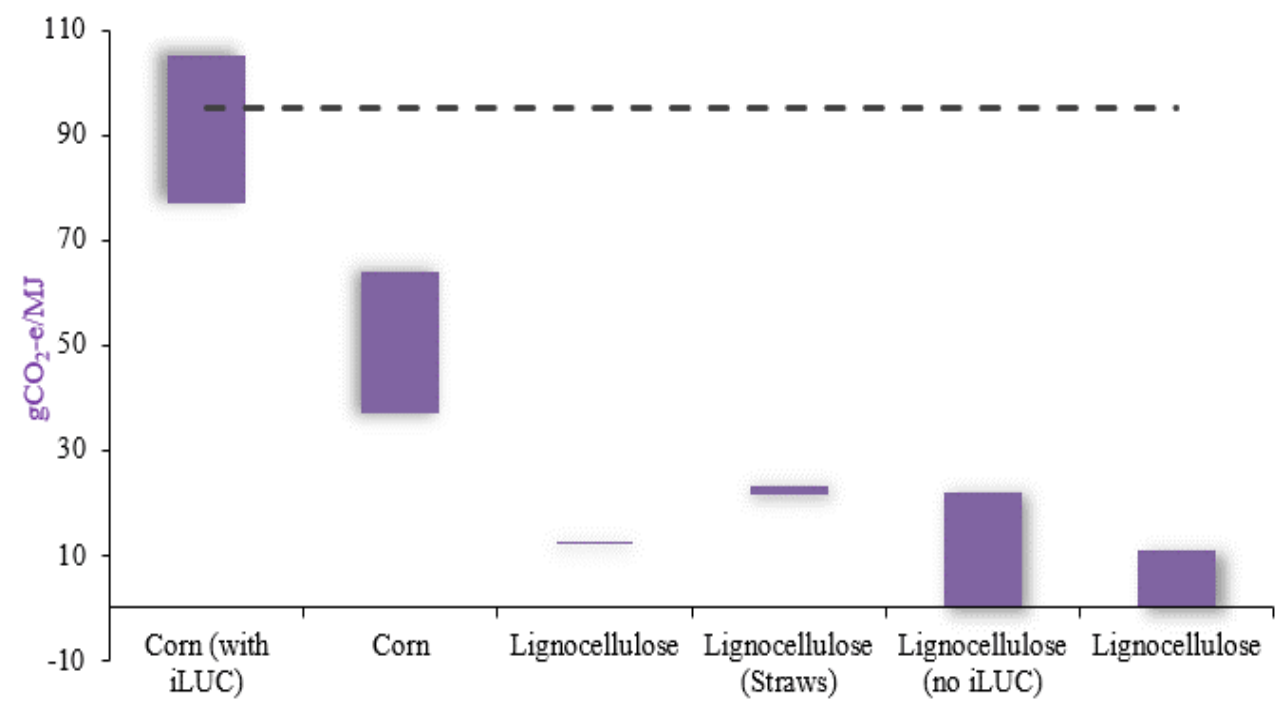

Source: Based on Eisentraut (2010a), Hamelinck, De Loveinfosse, and Koper (2012), and Purohit and Fischer (2014)

Figure 1. Range of GHG emission from different sources

The GHG saving by advanced biofuels depends on the production pathway through which the biofuel is produced (Zah, 2007). Table 2 shows the mitigation of GHG emission by the cellulosic ethanol reported by different studies. Studies reported the diverse range of GHG savings. The range of GHGs savings is in between $10 \%-102 \%$. In most of the cases, GHGs savings is more than $50 \%$ and usually around $80 \%$ (Table 2).

Table 2. GHG emission savings from the advanced biofuels

\begin{tabular}{ccc}
\hline Study & GHGs savings & Source \\
\hline Farrell & $88 \%$ & (Farrell, 2006) \\
\hline Edwards & $76-88 \%$ & (Ackom, Emmanuel; Mabee, Warren, and Saddler, 2010) \\
\hline Grood & $93-98 \%$ & (Groode and Heywood, 2007) \\
\hline Unnash & $10-102 \%$ & (Unnasch and Pont, 2007) \\
\hline Wang & $86 \%$ & (Wang, Wu, and Huo, 2007) \\
\hline Zah & $80 \%$ & (Zah, 2007) \\
\hline Pallav & $80 \%$ & (Purohit and Fischer, 2014) \\
\hline Wang & $85 \%$ & (Wang, 2005) \\
\hline
\end{tabular}

\section{Carbon Sequestration by the Cultivation of Lignocellulosic Feedstock}

Energy crops, if cultivated on marginal lands and through afforestation of the deforested areas with fast growing tree species we could create a carbon sink. As the plantation grows, it captures atmospheric carbon and converts it into biomass. For instance, a study reported the carbon sequestration from cultivation of Miscanthus as $\sim 1$ tone from one hectare in one year (1 tC/ha/yr) (Anderson-Teixeira et al., 2009). Another study reported that the carbon sequestration from Miscanthus on grassland is around $0.4-0.5 \mathrm{tC} / \mathrm{ha} / \mathrm{yr}$ and $0.55-0.65 \mathrm{tC} / \mathrm{ha} / \mathrm{yr}$ on the pasture land (Dunn et al., 2013). Repeated plantation of successional herbaceous plants on marginal land shows a considerable positive impact on GHG savings. For instance, a study reported $800-900 \mathrm{gCO}-\mathrm{e}$ mitigation capacity from the production of successional herbaceous plants (Gelfand et al., 2013). In comparison with that, corn vegetation has only $370-430 \mathrm{gCO}_{2}$-e mitigation capacity (Gelfand et al., 2013).

\section{SOCIOECONOMIC IMPACTS}

The socioeconomic impacts of biofuel industry could be measured by its positive impact on income and employment. Biofuel industry is making some measurable contributions to the individual income and employment and as well as global economy.

Most of the third world countries have a sizeable amount of agroforestry residue and marginal land. Till now, agroforestry residue is considered negligible in terms of economic value but if used for production of biofuels, their demand will increase either for domestic biofuel production or for export as a feedstock (International Energy Agency, 2012). The diversion of agroforestry residue will generate substantial economic value for agroforestry residues by balancing the forces of demand and supply (Eisentraut, 2010a). The prices paid as a payment of agroforestry residues will help in raising farmer's income and will have a positive impact on economic growth, poverty alleviation and food security (FAO, 2008).

Purposely cultivated feedstock i.e. energy crops have significant positive impact on the income of farming communities. Potential for job creation along the supply chain of advanced biofuel is significant (Figure 2). The jobs are created by cultivation 
of feedstock and will absorb low skilled poor workers of rural areas (Langevin, 2005). The quality of jobs is better for them because of the lower element of seasonality with possibility of increasing wages over time (Macedo, 1995). Moreover, because of cultivation on marginal land the energy crops do not compete with resources used for food production. Indeed, they may contribute to improving the food security which will help in avoiding the pressure on low-income consumers, particularly in developing countries (FAO, 2018).


Source: Author

Figure 2. Possibilities of job creation in the supply chain of advanced biofuels

\section{Income and Employment Impacts of Advanced Biofuels}

The production of advanced biofuels has a positive impact on the generation of income and employment. Currently, the advanced biofuels industry is in a developmental stage but the encouraging future impacts cannot be overseen. The market for advanced biofuels is expected to grow at the CAGR (compound annual growth rate) of $41.8 \%$ and projected to reach up approximately $\$ 100$ billion in 2023 from $\$ 8.64$ billion in 2016 (Stratistics, 2017).

Table 3 shows the income and employment impacts of advanced biofuels by a single plant constructed and operated in North Dakota. For the plant capacity of 50-million-gallon ethanol per year, around $\$ 36$ million will be needed to invest in the feedstock, which is $68 \%$ of the total expenditure. The payment for feedstock represents income to farmers (Table 3 ). The rest of the sectors of the economy also get benefited but the income impacts for farmers are more pronounced. Also, a total of 2,477 jobs were generated throughout the supply chain from the mentioned plant capacity. The plant employed 77 workers directly on a payroll of $\$ 2.7$ million. Also, about 2400 jobs are spread throughout the supply chain (Table 3) (Hodur and Leistritz, 2009).

Table 3. Direct economic impacts of cellulose based ethanol (\$ million)

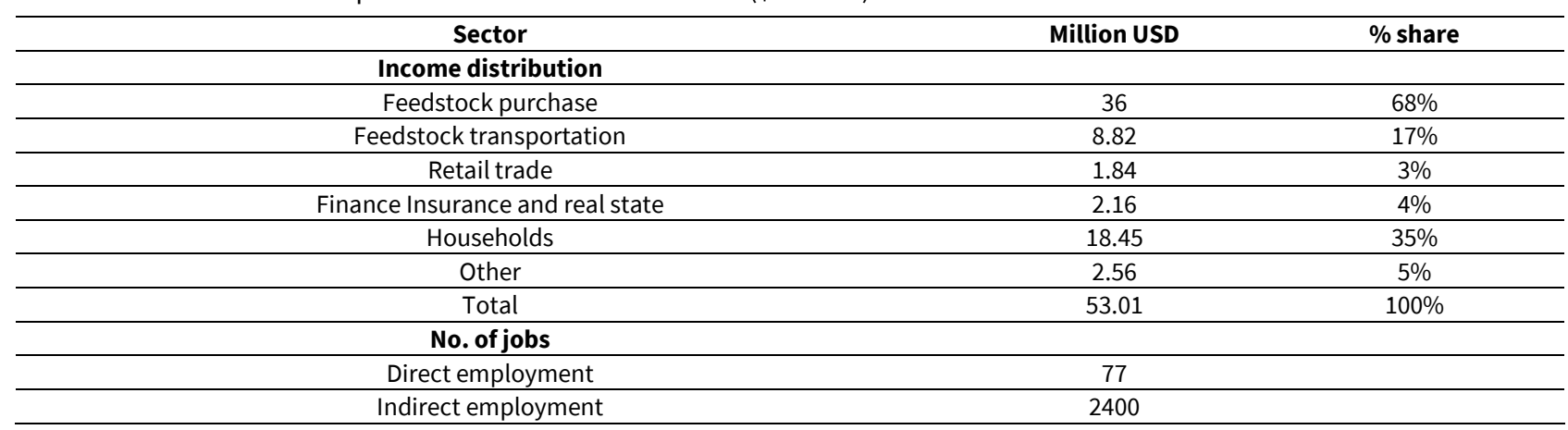

Source: (Hodur, Leistritz, and Hertsgaard, 2006)

\section{Impacts of Biofuel Industry on Income and Employment on Global Scale}

The information available about the income and employment effects by large scale production of advanced biofuels is limited because the industry is in development stage. Therefore, for evaluation of the income and employment effects of the advanced biofuels as an industry, it is assumed that the dynamics of spreading of these effects are the same as the conventional biofuel industry.

The production of ethanol has considerable positive impacts on global income and employment. For instance, the global production of ethanol in 2010 was around $93 \mathrm{Gl}$. This amount of production needs the investment of $\$ 87.3$ billion in feedstocks and other inputs. The return on this investment has a gross value of around $\$ 301.5$ billion along with a value added output of \$125.2 billion. Moreover, it supports 1.1 million jobs (Table 4). 
Table 4. Global impacts on income and employment by biofuels (2010)

\begin{tabular}{|c|c|c|c|c|c|}
\hline Biofuels & $\begin{array}{l}\text { Quantity of biofuels } \\
\text { giga litres (GI) }\end{array}$ & $\begin{array}{c}\text { Investment on feedstock } \\
\text { (billion USD) }\end{array}$ & $\begin{array}{c}\text { Gross Output in } 2010 \\
\text { (Million \$) }\end{array}$ & $\begin{array}{c}\text { Value added } \\
\text { output }\end{array}$ & No. of jobs \\
\hline Ethanol & 93 & 87.3 & 301,480 & 125.2 & $1,088,229$ \\
\hline Biodiesel & 17.6 & 21.6 & 72,952 & 30.3 & 291,129 \\
\hline Total & 100.16 & 108.9 & 374,432 & 155.5 & $1,379,358$ \\
\hline
\end{tabular}

Source: (Urbanchuk, 2012)

The global biodiesel production was $17.6 \mathrm{Gl}$ in 2010. This amount of production needed the investment of about $\$ 21.6$ billion on feedstocks and other inputs. The production of biodiesel generates $\$ 73$ billion of gross output, $\$ 30.3$ billion of values-added output and 3 million jobs (Table 4).

The total amount of biofuels is around $100 \mathrm{Gl}$ and demands the total investment of about $\$ 109$ billion. The return on this investment is $\$ 375$ billion in gross value and $\$ 155$ billion in terms of value added output (Table 4$)$. The total number of jobs created by conventional biofuel industry is around 1.4 million, spread throughout all sectors of the economy on the global scale.

\section{Income and Employment Impacts in Major Biofuel Producing Countries}

Table 5 shows the income and employment impacts by production of biofuels in top producing countries. USA and Brazil are two biggest producers of fuel ethanol. The quantity of ethanol is around $50 \mathrm{Gl}$ in the USA and $26 \mathrm{Gl}$ in Brazil, which constitutes $54 \%$ and $28 \%$ share of the global ethanol production (Table 5). The income and employment generated by ethanol production is significant and generates gross revenue of $\$ 129$ billion in the USA and $\$ 111$ billion in Brazil (Table 5). Around 0.4 million jobs in USA and 0.44 million jobs in Brazil are created by production of ethanol. USA and Brazil jointly represents $37 \%$ and $41 \%$ of the global employment generated by the ethanol industry (Table 5). Ethanol production in India also have measurable income and employment effects. In 2010, around $2 \mathrm{Gl}$ of ethanol was produced in India which represents $2 \%$ of the global ethanol output, $3 \%$ of the gross value output and $3 \%$ of the global employment creation (Table 5).

Table 5. Income and employment impacts of biofuels

\begin{tabular}{|c|c|c|c|c|c|c|}
\hline \multirow[t]{2}{*}{ Country } & \multicolumn{2}{|c|}{ Biofuel output (Mil litres) } & \multicolumn{2}{|c|}{ Gross output (Mil \$) } & \multicolumn{2}{|c|}{ No. of Jobs } \\
\hline & Ethanol & Biodiesel & Ethanol & Biodiesel & Ethanol & Biodiesel \\
\hline U.S. & $50.3(54)$ & $1.19(7)$ & $12.92(43)$ & $4.9(7)$ & $400677(37)$ & $19713(7)$ \\
\hline Brazil & $26.2(28)$ & $1.55(9)$ & $111.35(37)$ & $6.4(9)$ & $444378(41)$ & $25633(9)$ \\
\hline EU-27 & $4.46(5)$ & $9.18(52)$ & $17.4(6)$ & $38(52)$ & $69343(6)$ & $151840(52)$ \\
\hline India & $1.89(2)$ & $1.79(1)$ & $8.1(3)$ & $0.74(1)$ & $32088(3)$ & $2967(1)$ \\
\hline Other & $1.04(11)$ & $5.5(31)$ & $35.5(12)$ & $22.8(31)$ & $141743(13)$ & $90976(31)$ \\
\hline Total & 93 & 17.6 & 301 & 73 & 1088229 & 291129 \\
\hline
\end{tabular}

Source: (Urbanchuk, 2012),

* the value in parenthesis () shows percentage contribution in total. Value in (\$2010)

European Union is the number one producer of biodiesel. In 2010, around $9 \mathrm{Gl}$ of biodiesel was produced in the EU, which represents $52 \%$ of the global biodiesel production. The income and employment impacts of biodiesel production are significant in the EU. In 2010, $\$ 38$ billion gross value worth of biodiesel was produced in the EU and 0.15 million jobs were created which represents $52 \%$ of the global job creation by biodiesel production (Table 5). Biodiesel production in India has measurable income and employment effects. In 2010, around $2 \mathrm{Gl}$ of biodiesel was produced in India. It represents the $1 \%$ of the global biodiesel output, $1 \%$ of the gross value output and $1 \%$ of the global employment generation (Table 5).

\section{Industrial Breakdown of Income and Employment Impacts of Biofuel Production}

It is pertinent to identify most important and benefited sectors of the economy and the sectoral distribution of income and employment in order to understand the impact of biofuel production on economy. Table 6 indicates that, the income and employment impacts of ethanol production is distributed in approximately all sectors of the economy. From ethanol production in USA, income of around $\$ 23$ billion and 0.35 million jobs are generated (Table 6).

In terms of income, agriculture sector is the most benefited sector of the economy. It generates income of about $\$ 9$ billion which represents $39 \%$ of the total income generated in the USA via ethanol production. The number of jobs created in agriculture sector via ethanol production is around 81734 , which represents $23 \%$ of the total jobs (Table 6 ). In terms of job generation, the service sector dominates over other economic sectors and generates 146218 jobs which represents $41 \%$ of the total jobs in the ethanol industry. In terms of income, service sectors generate $\$ 7.2$ billion which represents $31 \%$ of the total income from the ethanol production in USA (Table 6). 
Table 6. Breakdown of income and employment impacts (USA)

\begin{tabular}{|c|c|c|c|c|}
\hline Economic Sectors & No. of jobs & Income billion USD & $\%$ Share of jobs & $\%$ Share of income \\
\hline Agriculture & 81734 & 9.2 & $23 \%$ & $39 \%$ \\
\hline Mining & 5247 & 0.36 & $1 \%$ & $2 \%$ \\
\hline Construction & 18514 & 0.71 & $5 \%$ & $3 \%$ \\
\hline Manufacturing & 27569 & 2.75 & $8 \%$ & $12 \%$ \\
\hline Transportation/Public Utilities & 22570 & 1.16 & $6 \%$ & $5 \%$ \\
\hline Wholesale/Retail Trade & 52145 & 1.92 & $15 \%$ & $8 \%$ \\
\hline Services & 146218 & 7.28 & $41 \%$ & $31 \%$ \\
\hline Government & 3410 & 0.22 & $1 \%$ & $1 \%$ \\
\hline Total & 357407 & 23.5 & $100 \%$ & $100 \%$ \\
\hline
\end{tabular}

Source: (Urbanchuk, 2014) values in (\$2015)

\section{CONCLUSION}

This study has reinforced the notion of positive impacts of advanced biofuels on the environment and socioeconomic conditions. Larger greenhouse gas benefits from advanced biofuels are observed in this study. Because of the inclusion of literature concerned with the elaborated analysis of life cycle emissions of advanced biofuels in addition to the carbon sequestration potential by the cultivation of energy crops. Due to larger GHG savings, the climatic benefits of advanced biofuels will be more pronounced and have potential to mitigate climate change if used on a large scale for a long time. But sustainability considerations regarding land use change and decarbonisation of the supply chain are the preconditions to achieve aforementioned GHG benefits. The potential for generation of income and employment by production of advanced biofuels is observed throughout the whole supply chain. The potentials for income and employment benefits from advanced biofuels production are found to be significantly beneficial for the farmers. The feedstock trade places considerable positive effects on the employment and income of farmers. Other sectors of the economy involved in supply chain of advanced biofuels also get benefited. This study strengthens position of advanced biofuels as a strong alternate of petroleum based transport fuels with the aforementioned benefits. What left is the large scale uptake of production and application of advanced biofuels to reap aforementioned benefits, which are not achievable without a proper policy and monetary support from the public sector.

\section{ACKNOWLEDGEMENTS}

The author is thankful to Aligarh Muslim University, Aligarh, UP, India for providing basic support during the research work.

\section{REFERENCES}

Ackom, E., Mabee, W. and Saddler, J. (2010). Backgrounder: Major Environmental Criteria of Biofuel Sustainability. (June), p. 39.

Anderson-Teixeira, K. J., et al. (2009). Changes in soil organic carbon under biofuel crops. GCB Bioenergy. https://doi.org/10.1111/j.1757-1707.2008.01001.x

Araújo, K., et al. (2017). Global Biofuels at the Crossroads: An Overview of Technical, Policy, and Investment Complexities in the Sustainability of Biofuel Development. Agriculture, 7(4), 32. https://doi.org/10.3390/agriculture7040032

Change, I. P. on C. (2015). Climate change 2014: Mitigation of climate change. Cambridge University Press.

Demirbas, A. (2008). Biofuels sources, biofuel policy, biofuel economy and global biofuel projections. Energy conversion and management, 49(8), 2106-2116. https://doi.org/10.1016/j.enconman.2008.02.020

Demirbas, A. (2009). Combustion efficiency impacts of biofuels. Energy Sources, Part A, 31(7), 602-609. https://doi.org/10.1080/15567030701743718

Demirbas, A. (2009). Political, economic and environmental impacts of biofuels: A review. Applied Energy, 86(SUPPL. 1), $108-117$. https://doi.org/10.1016/j.apenergy.2009.04.036

Dunn, J. B., et al. (2013). Land-use change and greenhouse gas emissions from corn and cellulosic ethanol. Biotechnology for biofuels, 6(1), 51. https://doi.org/10.1186/1754-6834-6-51

Eisentraut, A. (2010a). Sustainable Production of Second-generation Biofules, IEA Energy Papers. https://doi.org/10.1787/9789264084247-en

Eisentraut, A. (2010b). Sustainable Production of Second-generation Biofuels. Paris.

Eisentraut, A., Brown, A. and Fulton, L. (2011). Technology roadmap: biofuels for transport, International Energy Agency. Paris. https://doi.org/10.1002/bbb.330

FAO (2008). The State of Food and Agriculture. Biofuels: Prospects, Risks and Opportunities. FAO Report. Food and Agriculture Organization. Available at: http://www.fao.org/3/a-i0100e.pdf

FAO (2018). Energy. Available at: http://www.fao.org/energy/bioenergy/en/ 
Farrell, A. E. (2006). Ethanol Can Contribute to Energy and Environmental Goals. Science, 311(5760), 506-508. https://doi.org/10.1126/science.1121416

Gelfand, I., et al. (2013). Sustainable bioenergy production from marginal lands in the US Midwest. Nature, 493(7433), 514-517. https://doi.org/10.1038/nature11811

Greene, N., et al. (2004). Growing energy: How biofuels can help end America's oil dependence (Natural Resources Defense Council). New York. Available at: https://www.cabdirect.org/cabdirect/abstract/20053038944

Groode, T. A. and Heywood, J. B. (2007). Ethanol: A look ahead. Massachusetts Institute of Technology, Cambridge, MA.

Hamelinck, C. N. and Faaij, A. P. C. (2006). Outlook for advanced biofuels, Energy Policy. Elsevier. https://doi.org/10.1016/j.enpol.2005.06.012

Hamelinck, C., De Loveinfosse, I. and Koper, M. (2012). Renewable energy progress and biofuels sustainability. Ecofys, London, 450. Available at: https://ec.europa.eu/energy/sites/ener/files/documents/Final\%20report\%20-November\%202014.pdf

Hodur, N. M. and Leistritz, L. (2009). Economic impacts of biofuel development. AgMRC Renewable Energy Newsletter. February. Available at: https://www.agmrc.org/renewable-energy/renewable-energy-climate-change-report/renewable-energyclimate-change-report/february-2009-newsletter/economic-impact-of-biofuel-development

Hodur, N. M., Leistritz, F. L. and Hertsgaard, T. (2006). Contribution of the North Dakota Agricultural Products Utilization Commission programs to the state economy. North Dakota State University, Department of Agribusiness and Applied Economics. Available at: https://ageconsearch.umn.edu/record/23653/?ln=en

IEA (2015). Recent trends in world CO2 emissions from fuel combustion. Available at: https://www.iea.org/media/news/2015/news/151104_webarticle_CO2_FINAL.pdf

Ilyama, M. Kariuki, P., Kristjanson, P., Kaitibie, S. and Maitima, J. (2008). Transport and its infrastructure. Journal of International Development, 380-397. https://doi.org/10.1002/jid.1419

International Energy Agency (2012). World Energy Outlook 2012, IEA. https://doi.org/10.1787/weo-2012-en

Khan Akram A., Rahil Akhtar, U. and Anis, A. M. (2016) 'Cellulosic ethanol (energy security and climate change mitigation): A review', Biofuels. 7(2), 71-78. https://doi.org/10.5958/0976-4763.2016.00010.6

Kheshgi, H. S., Prince, R. C. and Marland, G. (2000). The potential of biomass fuels in the context of global climate change: focus on transportation fuels. Annual review of energy and the environment, 25(1), 199-244. https://doi.org/10.1146/annurev.energy.25.1.199

Ladanai, S. and Vinterbäck, J. (2010). Biomass for energy versus food and feed, land use analyses and water supply. Available at: https://pub.epsilon.slu.se/5562/1/ladanai_et_al_110104.pdf

Langevin, M. (2005). Fuelling Sustainable Globalization: Brazil and the Bioethanol Alternative. InfoBrazil, Sept, 17-23.

Larson, D. E. and Larson, E. D. (2008). Biofuel production technologies: status, prospects and implications for trade and development, United Nations Conference on Trade and Development. Geneva. Available at: http://unctad.org/en/docs/ditcted200710_en.pdf

Lynd, L. R. (1996). Overview and evaluation of fuel ethanol from cellulosic biomass: Technology, economics, the environment, and policy. Annual Review of Energy and the Environment, 21, 403-465. https://doi.org/10.1146/annurev.energy.21.1.403

Macedo, I. d C. (1995). Converting biomass to liquid fuels: making ethanol from sugar cane in Brazil. Energy as an Instrument for Socio-Economic Development. J. Goldemberg and TB Johansson, United Nations Development Program, New York, USA. Available at: http://www.nzdl.org/gsdlmod?e=d-00000-00---off-0cdl--00-0----0-10-0---0---0direct-10---4-------0-0l--11-en-50---20-about--00-0-1-00-0--4----0-0-11-10-0utfZz-8-00\&a=d\&c=cdl\&cl=CL2.5\&d=HASH30973bf1c70f9fe7edf8d1.6.2\#HASH30973bf1c70f9fe7e df8d1.6.2

Pauly, M. and Keegstra, K. (2008). Cell-wall carbohydrates and their modification as a resource for biofuels. Plant Journal, 54(4), 559-568. https://doi.org/10.1111/j.1365-313X.2008.03463.x

Petroleum, B. (2013) BP biofuels fact sheet. Available at: www.bp.com/content/dam/bp-alternate.../en/.../bp-biofuelsfactsheet.pdf

Purohit, P. and Fischer, G. (2014). Second-generation biofuel potential in India: Sustainability and cost considerations. Available at: http://pure.iiasa.ac.at/id/eprint/11187/

Ribeiro, S. K., et al. (2007). Transportation and its Infrastructure. IDEAS Working Paper Series from RePEc. Available at: http://search. proquest.com/docview/1698189351?accountid=10297\%5Cnhttp://sfx.cranfield.ac.uk/cranfield?url_ver=Z39.88-2004\&rft_val _fmt=info:ofi/fmt:kev:mtx:journal\&genre=preprint\&sid=ProQ:ProQ\%3Aabiglobal\&atitle=Transportation+and+its+Infrastruct ure\&title $=$

Sakthivadivel, D. and Iniyan, S. (2018). Characterization, density and size effects of fuels in an advanced micro-gasifier stove. Biofuels. https://doi.org/10.1080/17597269.2018.1426163

Sakthivadivel, D., et al. (2019). Performance Study of an Advanced Micro-gasifier Stove with Coconut Shell. European Journal of Sustainable Development Research. https://doi.org/10.29333/ejosdr/5905

Stratistics (2017). Advanced Biofuels - Global Market Outlook (2017-2023). Available at: https://www.strategymrc.com/report/advanced-biofuels-market

Tanaka, N. (2010). World energy outlook 2010, International Energy Agency. Paris: IEA. Available at: https://www.energy.eu/publications/weo_2010-China.pdf (Accessed: 4 September 2017). 
Unnasch, S. and Pont, J. (2007). Full Fuel Cycle Assessment: Well-to-wheels Energy Inputs, Emissions, and Water Impacts: Preparation for the $A B 1007$ (Pavley) Alternative Transportation Fuels Plan Proceeding. California Energy Commission. Available at: http://www.energy.ca.gov/2007publications/CEC-600-2007-002/CEC-600-2007-002-D.PDF

Urbanchuk, J. M. (2012). Contribution of biofuels to the global economy. Available at: https://advancedbiofuelsusa.info/contribution-of-biofuels-to-the-global-economy/

Urbanchuk, J. M. (2014). Contribution of the Ethanol Industry to the Economy of the United States. pp. 1-11. Available at: https://ethanolrfa.org/wp-content/uploads/2015/09/2012-Ethanol-Economic-Impact.pdf

Wang, M. (2005). Energy and greenhouse gas emissions impacts of fuel ethanol. Center for transportation research energy system division, Argonne National Laboratory. NGCA Renewable fuels forum, the national Press club. Available at: https://www.researchgate.net/profile/Michael_Wang14/publication/228787542_Energy_and_greenhouse_gas_emissions_i mpacts_of_fuel_ethanol/links/549445e70cf2d593b9610a39.pdf

Wang, M., Wu, M. and Huo, H. (2007). Life-cycle energy and greenhouse gas emission impacts of different corn ethanol plant types. Environmental Research Letters, 2(2). https://doi.org/10.1088/1748-9326/2/2/024001

Zah, R. (2007). Life Cycle Assessment of Energy Product: Environmental Assessment of Biofuels-Executive Summary. EMPA, 2007. Available at: https://www.osti.gov/etdeweb/biblio/21208801 